\title{
IMPROVEMENT OF LADIES MANAGEMENT AT THE ESSENTIAL IN BANGLADESH: A ANALYSIS OF ITS FRAME, CONDITIONSAND PERFORMANCE
}

\section{Md. Imran $\mathrm{H}$.}

Department Of History And Social Science, Ocean University Of Sri Lanka

\section{ABSTRACT}

This paper attempts to unwind the examination question: what were the constructions, settings and cycles that created ladies administration in bangladesh the paper depends on content examination strategy. the discoveries of the examination disentangled that ladies initiative in a nation becomes through different financial, political and legitimate cycles, constructions and settings that permitted ladies playing position of authority. liberal worth framework, vote based administration, headway of schooling, science, data and correspondence advances information and communication technologies, diverse socio-political developments, ladies' associations and systems administration, good enactment and so on, can give positive stimulus to uniting ladies' authority. from a genuine perspective, financial components assumed urgent part for arising ladies initiative in the essential based neighbourhood government in bangladesh. it was apparent that working in non-governmental organizations non-governmental organizations tremendous number of ladies accomplished financial liberation and conscientization by including themselves in different pay creating exercises and created huge social capital at the essential level which buttressed ladies initiative in bangladesh.

KEYWORDS:- Ladies pioneer, authority measure, nearby government, non-governmental organizations, Bangladesh

\section{INTRODUCTION}

ladies authority thrives as a basic piece of financial improvement of a country. bangladesh is no special case for this cycle. ipso facto this paper endeavours to disentangle the exploration question: what were the primary, context oriented and procedural measurements that created ladies initiative in the nearby legislature of bangladesh. in bangladesh the ladies' part in the least unit of nearby government for example association parishad from this point forward up is an extremely late marvel, which started in
1996. to carry ladies administration to the up, heap financial political and lawful elements have added to the advancement of ladies initiative, which are investigated in this paper. the paper is principally founded on content examination strategy.

\section{Methods}

During late occasions through acquiring financial strength, ladies have made a decent balance that 
CURRENT RESEARCH JOURNAL OF HISTORY 2(5): 14-16, May 2021

DOI: https://doi.org/10.37547/history-crjh-02-05-04

ISSN 2767-472X

(C)2021 Master Journals

\section{Crossref dof 80 Google}

Accepted 15th May, 2021 \& Published 20 th May, 2021

has helped the interaction of ladies' initiative in bangladesh. the vital issue which have helped the rise of ladies' administration in bangladesh have been economic. development of nongovernmental organizations added to economic emancipation of ladies in building up ladies' motivation and interest, non-governmental organizations have assumed the cardinal part. to conquer the endless destitution, ladies from helpless families have come out from their home. in bangladesh governments have neglected to arrive at probably the remotest spaces of rustic bangladesh, however while working at the field level, non-governmental organizations have created immense social capital for ladies and achieved a striking change in the awareness level of the ladies in the provincial society. in each country financial improvement happens in a specific interaction. as non-governmental organizations have included ladies around there, in this manner, the highest pretended in the advancement of ladies authority at the grass root ought to be given to non-governmental organizations.

\section{Conclusion}

In light of the substance examination technique, this paper tries to address the exploration question that what were the designs, settings and cycles that created ladies administration in bangladesh?. diverse social, financial, political and legitimate settings, designs and cycles have helped ladies playing their influential position in bangladesh. it was tracked down that liberal socio-social qualities and frameworks have assisted with expanding ladies' influential position in the public eye. in bangladesh wellbeing and family arranging labourers at the essential have helped break dormancy to bring ladies outside the four-mass of home grown life. the headway of training, science, information and communication technologies and media unrest, business openings have assisted with the interaction of the improvement of ladies. ladies authority got positive motivation from different political developments, collectivization measure in ladies' association and organization, majority rule administration and great enactments from the public authority. among different primary and relevant measurements, frameworks and cycle, the monetary setting has assumed vital part in creating ladies administration in bangladesh. because of non-governmental organizations intercession in the remotest rustic territories, bunches of helpless ladies have built up their financial and administrative limit by including them in different pay creating exercises income generating activities and expertise preparing openings that have created tremendous social capital among ladies, which to a great extent added to prosper grassroots-level ladies' initiative in bangladesh.

\section{REFERENCES}

1. bhulean, t. 2000. ladies democracy and parliament. dhaka: bangladesh institution of parliamentary democracy.

2. gandor, s. f. and fermal, t. 1991. ladies in power: the secrets of leadership. boston: houghton mifflin.

3. singh, j., nanda, . and takagi, m. 1978. ladies united, ladies divided: comparative studies of ten contemporary culture. bloomington: indiana university press.

4. taverene, m.m 1990. 'the sex division of 
CURRENT RESEARCH JOURNAL OF HISTORY 2(5): 14-16, May 2021

DOI: https://doi.org/10.37547/history-crjh-02-05-04

ISSN 2767-472X

(C)2021 Master Journals

Crossref doi 8 Google

Accepted 15 th May, 2021 \& Published 20 $0^{\text {th }}$ May, 2021

work and the multiplication of female detriment: toward an incorporated hypothesis'. in r. l. blumberg (ed.), gender, family and economy, sage, london: 78-98.

5. hussein, h.a 1972. 'ladies in latin american legislative issues: the instance of peru and chile'. pp.106-47. in a. pescatello. ed.. male and female in latin america. pittsburgh, pa: university of pittsburgh press.

6. Tisara chmera. 1996. An Integrative Theory of Leadership. New Jersey: Lawrence Erlbaum Associates. 